\title{
MONITORING OF RICE CROP IN PUNJAB AND HARYANA WITH RESPECT TO RESIDUE BURNING
}

\author{
Parmod Kumar*, Sudhir K. Rajpoot, Varunika Jain, Shalini Saxena, Neetu and S. S. Ray \\ Mahalanobis National Crop Forecast Centre, DAC\&FW, Pusa, New Delhi-110012, India (Parmod.nehra25, sudhir.iari, \\ varunika15jain)@gmail.com, shalini.85@gov.in, (neetu.ncfc, shibendu.ncfc)@nic.in
}

Commission III, WG III/10

Keywords: Rice residue, Burning, AWiFS, VIIRS and NDVI

\begin{abstract}
This study is based on the fortnightly monitoring of residue burning in fields of kharif rice crops after harvesting in Punjab and Haryana. The kharif rice area (2018-19) was derived using multi-date Sentinel-1A(Microwave SAR) data under FASAL project. The expected harvesting dates of kharif rice (crop duration 140 days) are derived on the basis of transplanting dates (derived from SAR data), NDVI profiles and Ground truth data. Daily active crop fire events in Punjab and Haryana were taken from VIIRS (Visible Infrared Imaging Radiometer Suite) product in the month of October and November 2018.It was observed from the study that the crop fire events showed a similar pattern as observed in expected harvest dates. Multi-date AWiFS data used to identify the crop residues- burnt areas during October and November 2018. The study reveals that maximum rice residue burning period is $2^{\text {nd }}$ fortnight of October to $1^{\text {st }}$ fortnight of November in both the states Punjab and Haryana. Maximum burning density was observed in the Mansa and Bhatinda district of Punjab and Fatehabad district of Haryana. In total 2.63 lakh ha burnt area was estimated in Haryana which is $20 \%$ of total kharif rice acreage while in Punjab it is 18.7 lakh ha (66\% of total kharif rice acreage). Thus this study could show the relationship between the satellites derived harvesting dates and the spread of crop fire events. Monitoring of crop residue burning at regular intervals especially before each crop harvesting season to ensure effective implementation of proactive measures to curb the practice of burning of crop residue.
\end{abstract}

\section{INTRODUCTION}

Crop burning is the practice of using fire to reduce or dispose of vegetative debris from an agricultural activity. The burning of stubble, contrasted with alternatives such as ploughing the stubble back into the ground has a number of consequences and effects on the environment. Stubble burning is the deliberate setting fire of the straw stubble that remains after wheat and other grains have been harvested (https://en.wikipedia.org/wiki/Stubble burning). Rice residue burning is a recurring problem, during October-November, in the northwestern regions (Punjab and Haryana) of India. The main cause of crop residue burning is that there is a very short window of time between harvesting of paddy and cultivation of wheat, at the end of the kharif season. India is an agrarian economy and generates around $600 \mathrm{Mt}$ of crop residues, from which $70 \%$ accounts for cereals, $13 \%$ of fibres, $6 \%$ of oilseeds, $3 \%$ of pulses, $2 \%$ of sugarcane and $6 \%$ of others (Jain et al., 2014). In November 2016, the Capital literally came to a standstill because of the smog created by the burning of crop residue in neighboring Haryana and Punjab. This practice has also become popular in other parts of the country. And today, the particulate matter emitted from crop burning across India in a year is more than 17 times the total annual particulate pollution in Delhi from all sources such as vehicles, garbage burning and industries. Burning of crop residue is a cause of concern because it leads to air pollution (Mittal et al., 2009).

The emissions from the residue burning source regions spread in all directions through long-range transport mechanisms, depending upon the meteorological conditions. In recent years, numerous studies have been carried out dealing with the impact of crop residue burning on the air quality of Delhi and surrounding areas. The burning of residue has been major environment concerned and cause substantial loss of plant nutrients and organic carbon. Rice residue burning produces a large amount of smoke in a short amount of time and hence concerns over impact to public health, (Kumar et al, 2015) safety and the environment. Punjab and Haryana contribute about 17 per cent of the total kharif rice production of the India. It has been estimated that on an average 40 per cent of the residue produced in these states burned in fields, while percentage is very lower in other rice growing areas. Satellite remote sensing is a very useful technology for monitoring the biomass burning at local and regional level. It provides us with means to measure the extent of burnt areas and potential proportions of burned surface area. The burned area mapping, aims at detecting and delineating the high residue burning area. The burned area mapping provides the assessment of area affected by fire. Burning of crop residue is a cause of concern because it leads to (Mittal et al., 2009) air pollution. Air pollutants released due to crop residue burning $-\mathrm{CH}_{4}, \mathrm{~N}_{2} \mathrm{O}$, $\mathrm{CO}_{2}$, Toxic gases $\left(\mathrm{NH}_{3}\right.$, NOx, SOx,VOCs (Volatile organic compounds) etc), Small particles, CO, NO, Aerosols, Particulates /soot/elemental C/black carbon, Smoke, Greenhouse gas emission Adverse health impacts (Asthma, and other respiratory illnesses) Nutrients loss. The present study has been attempted for regular monitoring of rice residue burning and area estimation of rice residue burning in 2 major paddy growing states of IGP, by using VIIRS\& AWiFS satellite data.

\section{STUDY AREA AND DATA SETS}

Two major rice producing states namely Punjab and Haryana, situated between $27^{\circ} 03$ ' $38^{\prime \prime}$ to $32^{\circ} 08^{\prime} 34^{\prime \prime} \mathrm{N}$ latitudes and $73^{\circ} 01^{\prime} 53^{\prime \prime}$ to $77^{\circ} 05^{\prime} 36^{\prime \prime}$ E longitudes, are selected for the study. The two states contribute more than $70 \%$ of the total rice

\footnotetext{
* Corresponding Author: parmod.nehra25@gmail.com
} 
residue burning in Indo-Gangetic plains region (Figure 1). The geographical area of these states is 50,362 and 44,212 sq. $\mathrm{km}$. respectively. The climate of region is very hot in summer and very cold in the winter. The region is generally dry and hot with maximum temperature of $43.1^{\circ} \mathrm{C}$ during May. The states have sub-tropical continental monsoon climate with hot summer and cool winter. The monsoon season lasts for three months with an annual rainfall of $688 \mathrm{~mm}$.

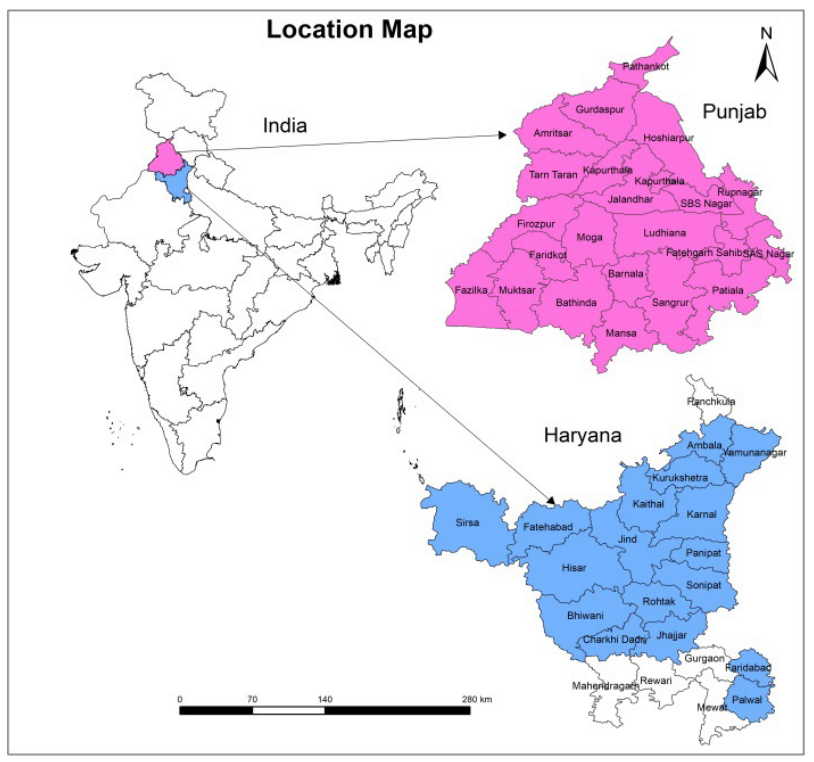

Figure1. Study area map.

Indian Remote Sensing Satellite (IRS Resourcesat-2 Advanced Wide Field Sensor (AWiFS, 56m spatial resolution) multi temporal data during October and November 2018 have been analyzed for estimating the extent of burnt areas from rice residue burning. Burnt area gives blackish impression on satellite images that can be identified. The 8-day MODIS/Terra composite data (MOD09Q1) with 250-meter resolution from June to November 2018 used to generate NDVI profile of kharif rice area. Earlier attempt has been made for Punjab using course resolution (Badarinath et. Al, 2006). The daily active fire events due to crop residue burning in Punjab and Haryana captured by VIIRS $\left(375 \times 750 \mathrm{~m}\right.$ spatial resolution) starting from $1^{\text {st }}$ October 2018 to $30^{\text {th }}$ November 2018 were acquired. The kharif rice area (2018-19) was derived using multi-date Sentinel-1A (SAR) data under FASAL project.

Satellite, sensor and acquisition dates for the data used during analysis are given in Table 1.

\begin{tabular}{cccc}
\hline State & $\begin{array}{c}\text { Study Crop } \\
\text { Residue }\end{array}$ & $\begin{array}{c}\text { Satellite \& } \\
\text { Sensor }\end{array}$ & $\begin{array}{c}\text { Date of } \\
\text { Acquisition }\end{array}$ \\
\hline & & & $12-10-2018$ \\
Punjab \& & & Resourcesat- & $16-10-2018$ \\
Haryana & Paddy & 2 AWiFS & $26-10-2018$ \\
& & & $30-10-2018$ \\
& & & $09-11-2018$ \\
& & & $19-11-2018$ \\
& & $24-11-2018$ \\
\hline
\end{tabular}

Table 1.IRS Satellite data used in crop residue burnt area estimation analysis.

\section{METHODOLOGY}

\subsection{Estimation of harvesting date using MODIS NDVI data}

The 8-day MODIS/Terra composite data (MOD09Q1) with 250-meter resolution was used from June to November 2018. The image data can be obtained every 8 day in the red and near infrared (NIR) spectral bands $(0.6 \mu \mathrm{m}-0.9 \mu \mathrm{m})$. Rice harvest dates are very useful information since they are the key factors in accessing rice residue burning period. It starts from the initial state or growing state which NDVI value starts to increase from NDVI value of bare soil (less than 0.2). NDVI profiles are the best way to show the phenological stage of the crop from sowing to harvesting. When rice grows to mature state, the NDVI value will be saturated.

\subsection{Collection and analysis of active fire events}

The daily active fire events due to crop residue burning in Punjab and Haryana were captured by VIIRS data starting from $1^{\text {st }}$ October 2018 to $30^{\text {th }}$ November 2018 . These points were geo-tagged with district and state boundary of Punjab and Haryana. District-wise daily fire events were extracted and cumulated to the state for computing total fire events. Rice crop mask and LULC mask are used to remove non-agricultural area. Fire event ratio for area and production were evaluated based on the number of fire events per thousand hectares and tons respectively.

\subsection{Estimation of kharif rice area and residue burning area}

The kharif rice area (2018-19) derived using multi-date Sentinel-1A (SAR) data (Neetu et. al, 2015) under FASAL project. For estimation of rice residue burning area, multi-date AWiFS satellite data images were used for digital image analysis. Satellite data were procured multidate, multi-scale keeping in view of timely and regular monitoring of crop residue burning and estimation of burnt area (Singh et al., 2009). Unsupervised classification technique was used for the classification of burnt areas. At the end, classified results from all dates were aggregated to estimate the total burnt area.

\section{RESULTS AND DISCUSSION}

4.1 Comparison of kharif rice growth pattern (from NDVI data) of selected Districts of Haryana, 2018 vis-à-vis average of 2015 to 2017

Figure $2 \& 3$ showed the rice growth pattern and comparison with last three years average to know harvesting date of rice in the study area. The analysis of MODIS NDVI data helps in understanding the rice harvesting date pattern and which helps to estimate residue burning period. Shudong et al,. 2018 also used the similar method to estimate NDVI profiles. The results showed that rice harvesting period and fire counts exhibit similar temporal pattern and coincide reasonably well with the fire counts. Figure $2 \& 3$ described the rice growth pattern from transplanting to harvesting to know about the window period for rice harvesting along with the comparison with last three years of average. An example of Mansa district of Punjab and Fatehabad district of Haryana is given in figure $2 \& 3$. It was observed from the study that in Punjab and Haryana, rice was mostly harvested during $1^{\text {st }}$ fortnight to $2^{\text {nd }}$ fortnight of October 2018 which indicated the window of residue burning too. 


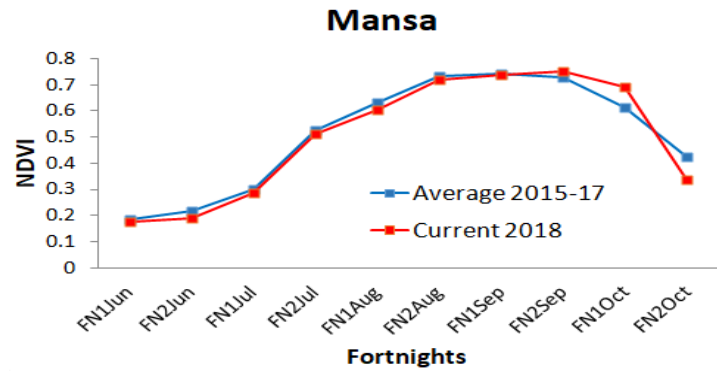

Figure 2. Rice growth pattern for estimation of harvesting pattern (from NDVI data) of Mansa district of Punjab, 2018 visà-vis average of 2015 to 2017

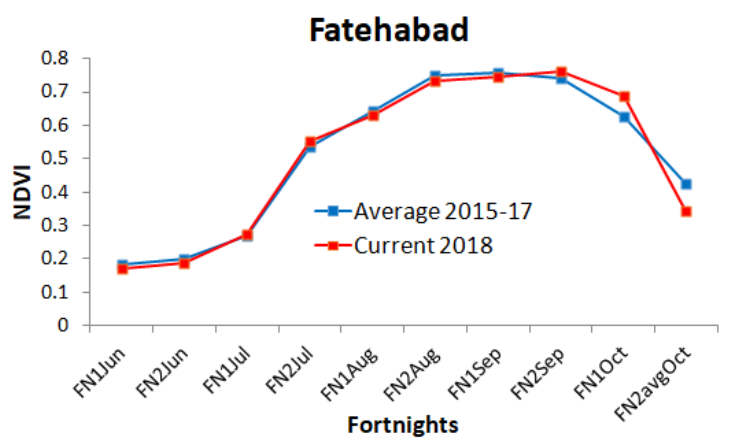

Figure 3. Rice growth pattern for estimation of harvesting pattern (from NDVI data) of Fatehabad district of Haryana, 2018 vis-à-vis average of 2015 to 2017

\subsection{Fortnightly comparison of active fire events detected by VIIRS data}

VIIRS acquired fire events (red points) in Punjab and Haryana from 1-Oct-2018 to 30-Nov-2018. Fortnightly maps of Punjab and Haryana are given in Figure 4 \& 5. Overall 64,377 and 10,226 fire events were captured by VIIRS in Punjab and Haryana, respectively during $1^{\text {st }}$ October to $30^{\text {th }}$ November 2018. In Punjab maximum fire events $(38,796)$ were captured on 1 st fortnight of November, followed by $2^{\text {nd }}$ fortnight of October with 18,265 fire events (Figure 5a). In Haryana $1^{\text {st }}$ fortnight of October and November shows about equal fire events compared to Punjab (Figure 5b). Above figure 4 shows that maximum frequency of fire events was observed in the central, western and southern districts of the Punjab. However, Northern and eastern districts of the Punjab show very less fire events.

\subsection{District wise comparison of maximum residue burning period}

The maximum district wise residue burning period in Punjab is observed during $4^{\text {th }}$ October to $1^{\text {st }}$ week of November and $1^{\text {st }}$ to $2^{\text {nd }}$ week of November. Whereas, in Haryana the maximum burning period was from $1^{\text {st }}$ to $2^{\text {nd }}$ week of November and $3^{\text {rd }}$ to $4^{\text {th }}$ week of November. (Figure $6 \& 7$ )

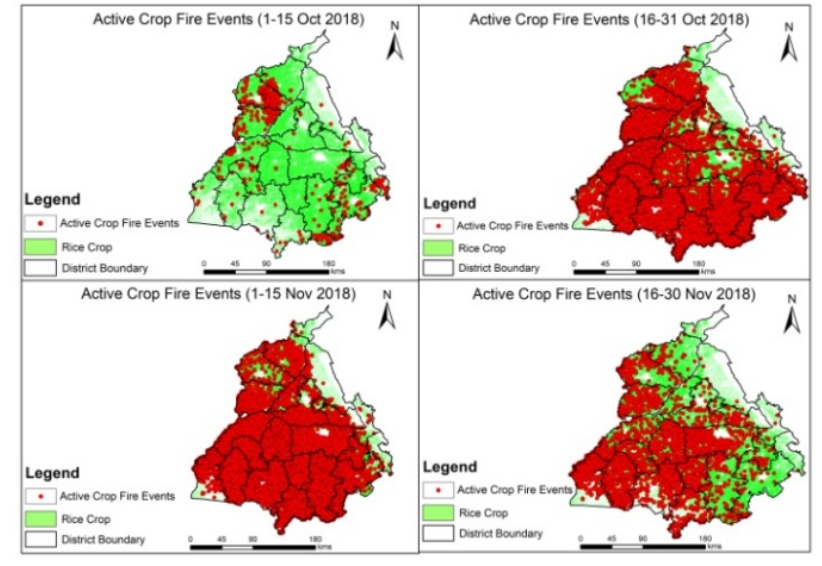

Figure 4. Fortnightly comparison of active fire events detected by VIIRS in Punjab from $1^{\text {st }}$ October 2018 to $30^{\text {th }}$ November 2018

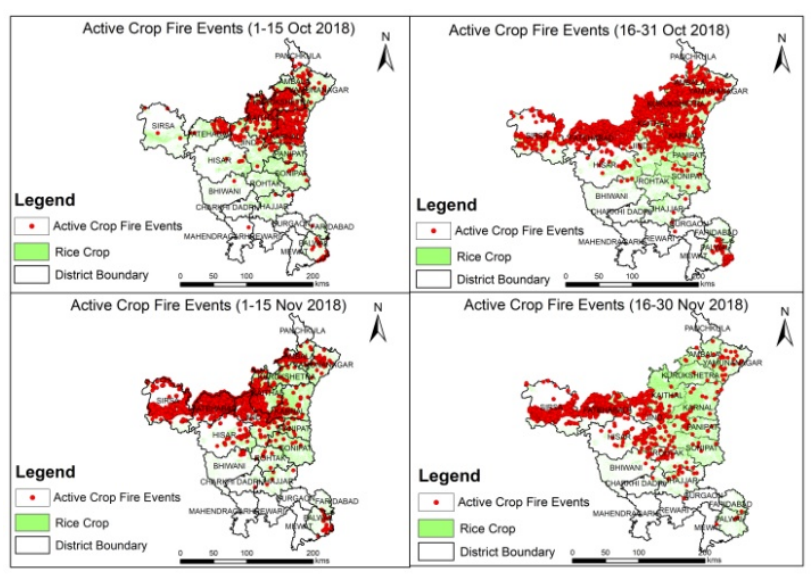

Figure 5. Fortnightly comparison of active fire events detected by VIIRS in Haryana from 1-Oct-2018 to 30-Nov-2018

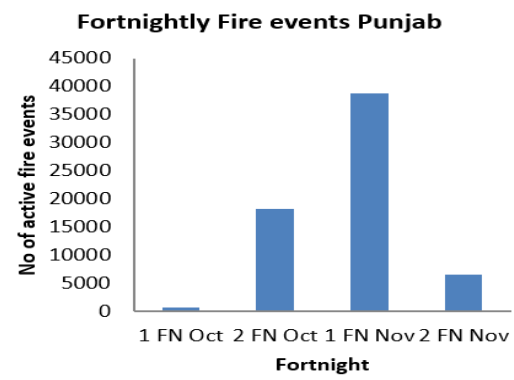

Figure 5a. Fortnightly comparison of active fire events in Punjab from 1-Oct-2018 to 30-Nov-2018

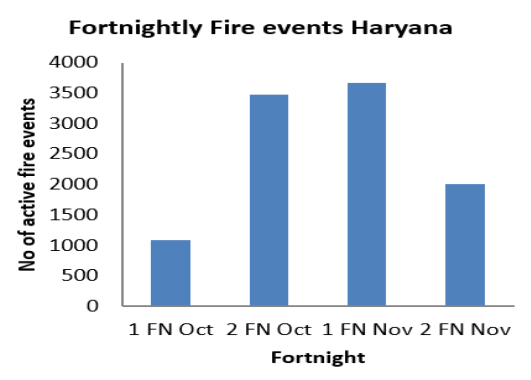

Figure 5b. Fortnightly comparison of active fire events in Haryana from 1-Oct-2018 to 30-Nov-2018 


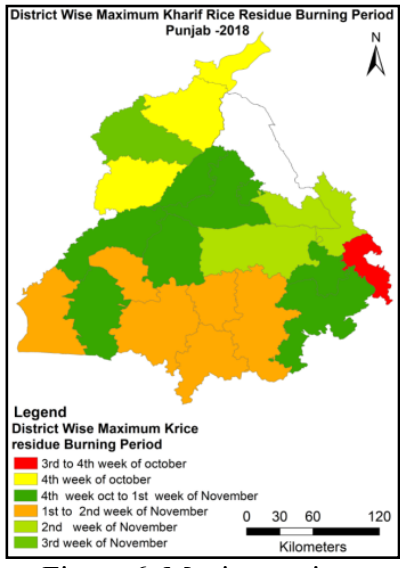

Figure 6. Maximum rice residue burning period of Punjab

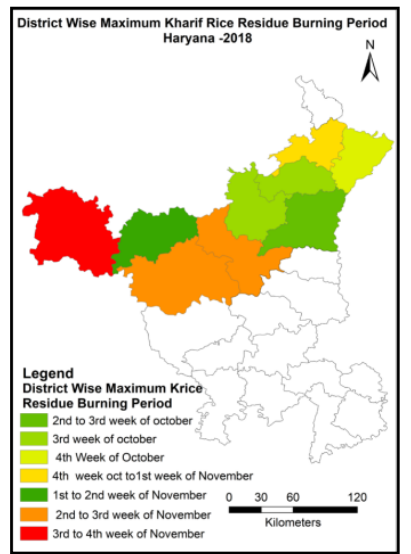

Figure7. Maximum rice residue burning period of Haryana

\subsection{District wise fire count percentage}

Figure 8 and 9 shows the district wise fire counts percentage in Punjab and Haryana. Sangrur, Firozpur and Bathinda districts contributes $>10 \%$ to the total fire counts, whereas, Majha and Doaba region districts contributes least which is less than 5\% to the total fire counts of residue burning in Punjab. This may be because of hilly terrain and diverse cropping system. Gurdaspur, Amritsar and Tarn Taran are traditional Basmati growing regions. Most of the harvesting is done till late November with manual cutting which leaves low amount of residue in the fields and hence resulted in less burning. Patiala, Moga, Mansa and Ludhiana and Muktsar contribute $5-10 \%$ of total fire counts of residue burning. In Haryana state, fire counts percentage is maximum in Fatehabad (29\%), followed by Sirsa (19\%) and Kaithal (14\%) districts and lowest percentage $<5 \%$ reported in Hisar, Ambala, Rohtak and Palwal.

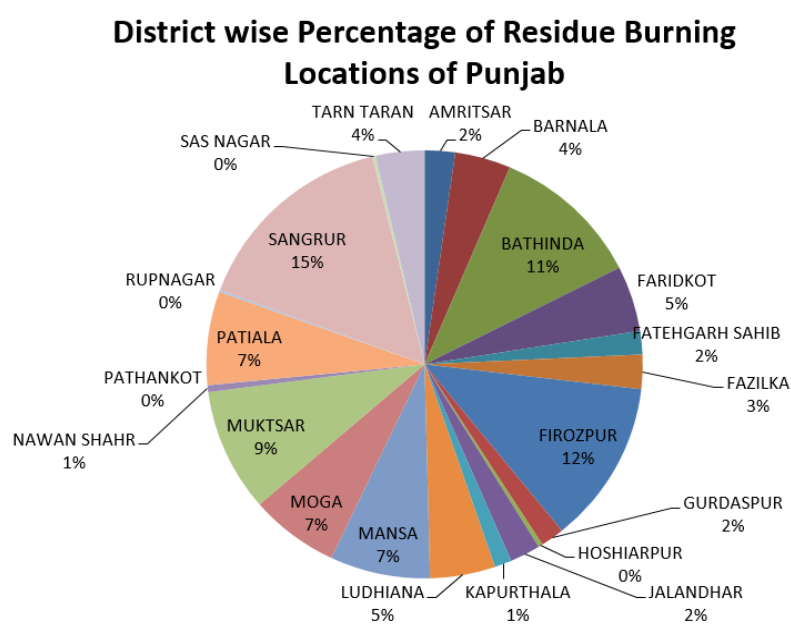

Figure 8.District wise fire counts percentage in Punjab

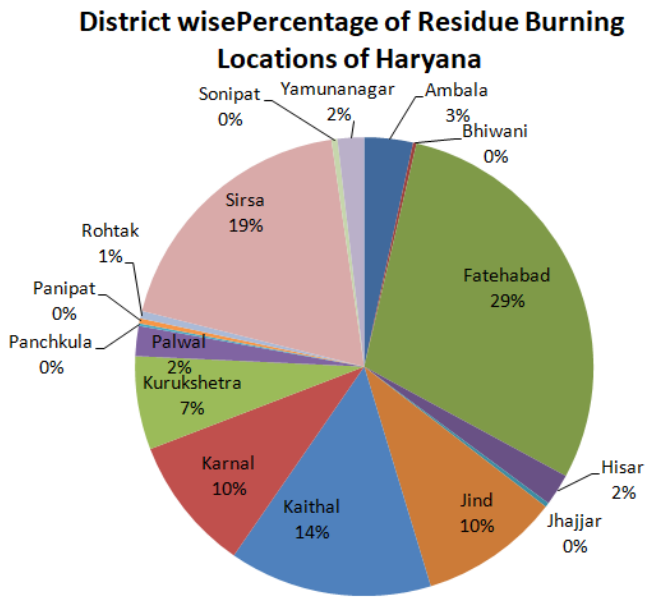

Figure 9. District wise fire counts percentage in Haryana

\subsection{Estimation of burning events to crop area ratio}

Figure $10 \& 11$ show the district wise burning events to crop area ratio over the period from $1^{\text {st }}$ October 2018 to $30^{\text {th }}$ November 2018. Maximum ratio of active fire events was observed in the Mansa and Bhatinda district followed by Muktsar and Firozpur Districts. The Low ratio of fire events was observed in the districts of Pathankot, Gurdaspur, Hoshiarpur, Rupnagar and Amritsar districts. In Haryana higher ratio of active fire events are observed only in Fatehabad district and lower ratio in Sonipat, Ambala, Yamunanagar, Hisar and Bhiwani districts. The number of burning events to rice area implies that the maximum rice areas have the maximum points of fire events. From the study it was observed that the districts under major rice, also showed the maximum number of fire points.

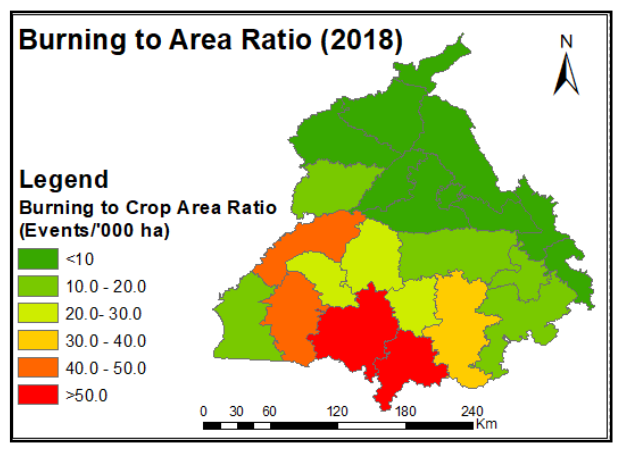

Figure 10. Burning events to crop area ratio in Punjab

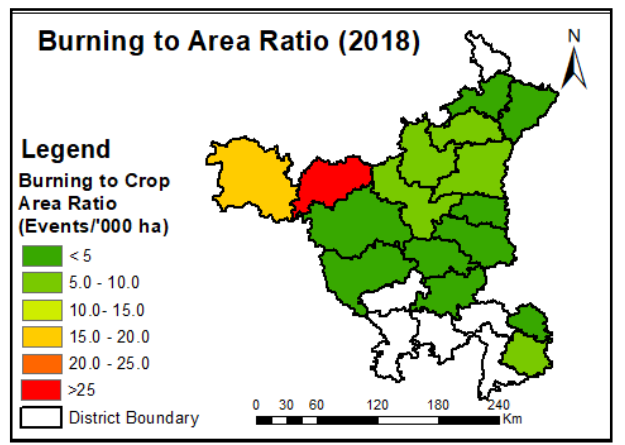


Figure 10. Burning events to crop area ratio in Haryana

\subsection{Date wise active crop fire events}

Figure $12 \& 13$ show the complete trend of rice residue burning over the period from $1^{\text {st }}$ October to $30^{\text {th }}$ November 2018 in Punjab and Haryana. Farmers started burning rice residue even before $15^{\text {th }}$ October but it picked up momentum after $15^{\text {th }}$ October and reached the peak during from $1^{\text {st }}$ to $2^{\text {nd }}$ week of November. From $3^{\text {rd }}$ week of November onwards, the residue burning shows decreasing trend. In Haryana the trend of rice residue burning is more fluctuating over the period compare to Punjab. In Haryana maximum residue burning period was observed during last week of October to $3^{\text {rd }}$ week of November. The report of Sandhu 2016 also indicated that early rice stubble burning in major area takes place during second to fourth week of October in Karnal, Kaithal, Kurukshetra, Ambala and Panipat. While late burning in major areas takes place during first week to third week of November in rest of the districts.

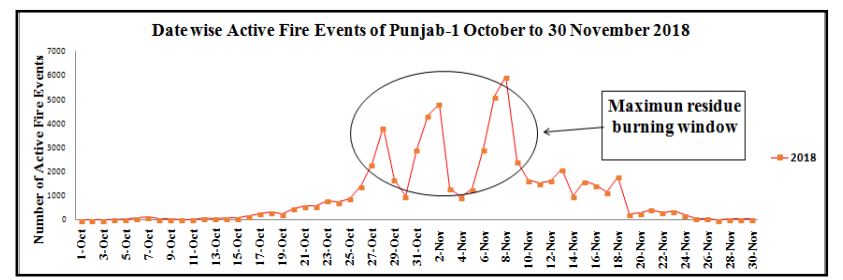

Figure 12.Date wise active crop fire events in Punjab

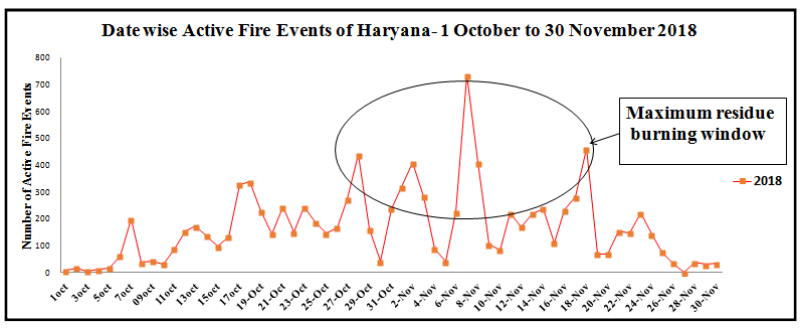

Figure 13. Date wise active crop fire events in Haryana

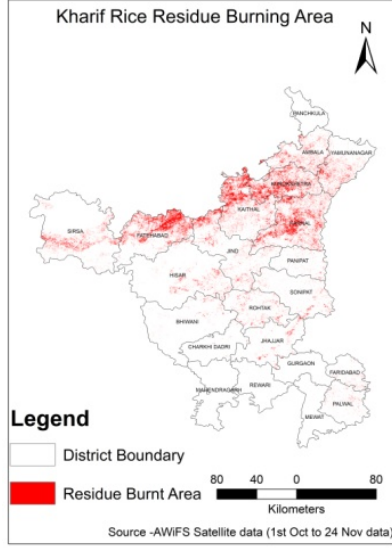

Figure 14. Rice Residue Burning Area Map of Haryana

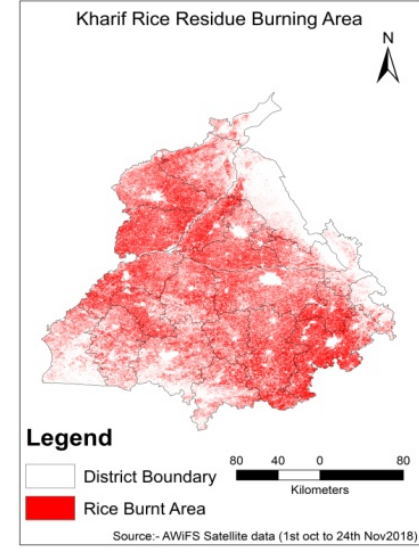

Figure 15 Rice Residue Burning Area Map of Punjab

\section{SUMMARY AND CONCLUSIONS}

In Punjab, major residue burning districts were Sangrur, Firozpur and Bathinda while least burning district area Ludhiana, Barnala, Pathankot and SBSnagar whereas, in Haryana, major burning districts are Fatehabad, Sirsa, Karnal and Kurukshetra while least burning districts are Sonipat, Panipat and Rohtak. The study indicates that maximum rice residue burning period in both the states is $2^{\text {nd }}$ fortnight of October to $1^{\text {st }}$ fortnight of November. Total 2.63 lakh ha and 18.7 lakh ha burnt area has been estimated (Figure 14\&15) in Haryana and Punjab respectively. Early estimation of harvesting dates and district wise assessment of maximum residue burning period will help the decision makers to curb the practice of rice residue burning in particular districts. Monitoring rice residue burning through satellite data using Remote Sensing and GIS will help the policy makers to access and implement policies to control the problem of residue burning.

\section{ACKNOWLEDGEMENT}

The work was carried out under the FASAL (Forecasting Agricultural output using Space, Agro-meteorology and Land based observations) of Department of Agriculture, Cooperation \& Farmers Welfare (DAC\&FW). The authors are thankful to the senior officials of DAC\&FW for their keen interest in the study. Thanks are due to the analysts of FASAL project for providing crop maps. Authors are also thankful to MODIS team for providing data for active fire events.

\section{REFERENCES}

Badarinath, K.V.S., T. R. Kiranchand and Krishna Prasad, V., 2006.Agriculture crop residue burning in the Indo-Gangetic Plains - A study using IRS-P6 AWiFS satellite data. Current Science 91(8), pp. 1085-1089.

Jain Niveta, Bhatia Arti and Pathak, H. 2014.Emission of Air Pollutants from Crop Residue Burning in India. Aerosol and Air Quality Research, 14: 422-430.

Kumar Parmod, Kumar Surender and Joshi Laxmi.2015. Socioeconomic and Environmental Implications of Agricultural Residue Burning A Case Study of Punjab, India p.137.

M. Yadav, R. Prawasi, S Jangra, and P Rana 2014.Monitoring seasonal progress of rice stubble burning in major rice growing districts of Haryana, India, using multidate AWiFS data. The International Archives of Photogrammetry, Remote Sensing and Spatial Information Sciences, 40(8), pp.1003-2014.

Mittal, S.K., Susheel, K., Singh, N., Agarwal, R., Awasthi, A. and Gupta, P.K. 2009.Ambient air quality during wheat and rice crop stubble burning episodes in Patiala. Atmos. Environ. 43: 238-244.

Neetu, Yeggina ,P. Magbul, S. and Ray, S.S. 2015. Seasonal Rice Crop Pattern Mapping using Multi-temporal Optical and SAR data ISG-ISRS National Symposium-2015 at Jaipur.

PRSC, 2015.Monitoring Residue Burning Through Satellite Remote Sensing, Punjab Remote Sensing Centre, Ludhiana. 
Sandhu Khushboo, Fields on fire: Burning paddy straw, The Indian Express, Kurukshetra, October 10, 2016.

Singh, G., Kant, Y. and Dadhwal ,V. K. 2009. Remote sensing of crop residue burning in Punjab (India): a study on burned area estimation using multi-sensor approach. Journal Geocarto International 24(4), pp 273-292.

Stubble burning available on. https:en.wikipedia.org/wiki Stubble burning, on 22/06/2017.

Vats Naresh $K$, Crop residues burning is detrimental to environment, International Journal of Law and Legal
Jurisprudence Studies.2(19). (http://ijlljs.in/wpcontent/uploads/2015/01/final-CROP-RESIDUE-BURNING-ADETRIMENTAL-TO-ENVIRONMENT.pdf)

Wang, S. Baig, M. H. A. Liu, S., Wan, H. Taixia Wu, and Yang., Y. 2018. Estimating the area burned by agricultural fires from Landsat 8 Data using the Vegetation Difference Index and Burn Scar Index. International Journal of Wildland Fire 2018, 27, 217-227. 